\title{
STUDY OF EFFECTS OF PULSED ELECTRIC FIELD ON SOWING QUALITIES
}

\author{
Galina Starodubtseva, Vladimir Khainovskiy, Elena Rubtsova, Oksana Kopylova
}

Stavropol State Agrarian University, Russia

sgp_starodubtseva@mail.ru,vl.khain@yandex.ru, elen.68rubtsova@yandex.ru, zolterxp@list.ru

\begin{abstract}
The article considers the presowing seed treatment by pulse electric field under the laboratory conditions to improve their sowing quality. The tests were carried out in each treatment mode in fourfold repetition with 100 seeds in each repetition to have reliable experimental data. The control was untreated seeds. The control and tested seeds had initial moisture content $-11 \%$. The control and tested seeds were put for germination into sterile Petri dishes on a bed of filter paper being wetted by distilled water. The analysis of the obtained experimental data was conducted by the methods of mathematical statistics with applying computer calculation according to the task-level programming. The following parameters suitable for practical application of the rational mode of presowing treatment of onion seeds were established: the amplitude and the voltage pulse duration were correspondingly equal to $200 \mathrm{~V}$ and $35 \mu \mathrm{s}$, pulse frequency $-600 \mathrm{~Hz}$, time treatment $-8 \mathrm{~s}$. At the same time, the seed germination energy was increased by $7.9 \%$ on the average, and germination by $8.5 \%$ compared with the control untreated seeds. The rational parameters of the presowing treatment mode of onion seeds have been obtained experimentally, allowing to increase the seed germination energy by $7.9 \%$ (up to $77.9 \%$ ), on the average and germination by $8.5 \%$ (up to $91 \%$ ) in comparison with the control untreated seeds. The given rational mode can be practically used to improve sowing quality of onion seeds prior their sowing.
\end{abstract}

Key words: amplitude, voltage, pulse frequency, presowing treatment, farm seeds, sowing quality.

\section{Introduction}

At present, presowing treatment of crop seeds by electromagnetic fields of different frequency (DC of corona discharge, sinusoidal low-frequency, high-frequency, microwave, pulse) to improve their sowing qualities is an actual ecological method.

There are some known publication works relevant to the treatment of both large-seeded crops (wheat, soya, rice, and French beans) and small-seeded crops (carrot, tomato, beet, onion) [1-13]. The effect of microwave electromagnetic radiation allows saving seeds from pathogenic microflora, which subsequently in future will positively affect the increase of power growth, plant vitality, and final yield [1-3]. As a rule, seed treatment by other electromagnetic fields is directed to improving their sowing qualities (germination energy and germination capacity) that can be supposedly explained by the field effect on the processes of intracellular metabolism of seeds [4-9].

However, the above mentioned authors do not put a question to optimize the modes of presowing seed treatment to apply them directly in practice. Previously, the authors of the given work carried out the laboratory research to find the rational (i.e. optimal for practice) modes of presowing treatment of some crops by the pulse electric field (PEF) [10-13]. PEF allows smoothly regulating treatment modes by means of smooth changes of voltage pulse amplitude, their frequency and duration.

The aim of the given work is to determine experimentally rational modes suitable for presowing treatment of onion seeds by the PEF to improve their sowing quality (germination energy and germination) in order to practise.

\section{Materials and methods}

The essence of presowing seed treatment by the PEF is that seed material is placed in a field at a certain time interval. The principal parameters of the modes of seed material treatment are the electric field strength $\left(\mathrm{V} \cdot \mathrm{m}^{-1}\right)$; pulse repetition frequency $(\mathrm{Hz})$, treatment time $(\mathrm{s})$; time after seed treatment up to their germination (during days). In the process of the method development, several installations of different designs were used for seed treatment depending on the realization of necessary processdependent parameters. An active zone of the installations represented an electric capacitor with plane metal electrodes and side walls made of dielectric. A gap thickness between electrodes could range from 50mmup to $100 \mathrm{~mm}$. The basic requirement to the installations was to create the electric field strength in the range of $4-20 \mathrm{kV} \cdot \mathrm{m}^{-1}$ in the active zone. Hence, when designing, it is necessary to know some electrical parameters of seeds: dielectric constant, leakage resistance, dielectric loss tangent, and humidity being determined by the known methods [14-16]. 
Initially, an experimental assembly was used with the voltage pulse amplitude $1500 \mathrm{~V}$, pulses duration $5 \mathrm{~ns}$, pulse repetition frequency $20-300 \mathrm{~Hz}$, the seed treatment time was $20-90 \mathrm{~min}$. The subsequent experiments demonstrated that it was possible to shorten considerably the treatment time at the expense of increasing the frequency and duration of voltage pulses, and also reducing greatly the amplitude of the pulses, while maintaining the necessary voltage of the electric field in the active zone. The field homogeneity was provided by air gap elimination over the seeds in the activator capacitor (i.e. solid filling of the volume). All this increased the installation productivity and its safety, also decreased its dimensions.

The presowing treatment of onion seeds was performed on the last modification of the installation with the parameters of the treatment mode presented in Table 1 [17-18]. In this case, duration of the processing time, frequency and duration of the voltage pulse were alternately varied.

Table1

Variants of the treatment modes of onion seeds

\begin{tabular}{|c|c|c|c|c|c|}
\hline $\begin{array}{c}\text { Pulse } \\
\text { repetition } \\
\text { frequency } \\
(\boldsymbol{f}), \mathbf{H z}\end{array}$ & $\begin{array}{c}\text { Pulse } \\
\text { duration, } \\
\left(\boldsymbol{\tau}_{\text {imp }}\right), \boldsymbol{\mu s}\end{array}$ & $\begin{array}{c}\text { Processing } \\
\text { Time }\left(\boldsymbol{t}_{\text {pro }}\right), \\
\mathbf{S}\end{array}$ & $\begin{array}{c}\text { Impulse } \\
\text { voltage }(\boldsymbol{u}), \\
\mathbf{V}\end{array}$ & $\begin{array}{c}\text { Layer } \\
\text { thickness of } \\
\text { seeds, } \mathbf{m}\end{array}$ & $\begin{array}{c}\text { Time after } \\
\text { treatment, } \\
\text { 24-hours }\end{array}$ \\
\hline $300-1000$ & $5-30$ & $3-9$ & $200-1000$ & $0.03-0.06$ & $3-5$ \\
\hline
\end{tabular}

The experiments were carried out on the onion certified seeds of variety "Holtsedon" with normative moisture $(11 \%)$. Seed moisture was determined by an electronic grain moisture meter WILE-65 (FARMCOMP, Finland). The seed sowing qualities were determined under the laboratory conditions. After treatment, the seeds were put for germination into sterilized Petri dishes on the bed of filter paper wetted by distilled water. Germination was done in the dark at temperature $23{ }^{\circ} \mathrm{C}$. Germination energy and germination capacity of seeds were estimated by the number of seedlings according to the standard procedure - GOST 12038-84. For reliability of the experimental data, the experiments were carried out in fourfold repetition with 100 seeds in each repetition. The control was untreated seeds.

\section{Results and discussion}

Theexperimental data arrays relating to the germination of onion seeds were processed by the methods of mathematical statistics using the electronic program "STATISTICS-6". Besides, three principal models were considered to determine the degree of the effect of the main parameters of the treatment modes on seeds germination. Preliminarily conducted correlation analysis gave the corresponding matrixes. It follows from these matrixes that the values of the correlation coefficients are similar to unity. Consequently, these coefficients are important and they should be taken into account, when mathematical models are defined (regression equations). In particular, the correlation matrix is demonstrated in Table 1 for the first model for the following parameters under study: $x_{1}-$ processing time $\left(t_{\text {pro }}\right), \mathrm{s} ; x_{2}$ - duration of voltage pulse $\left(\tau_{\text {imp }}\right), \mu \mathrm{s} ; y_{1}$ - seeds energy germination, $\%$.

Table2

Correlation matrix for $x_{1}, x_{2}, y_{1}$

\begin{tabular}{|c|c|c|c|c|c|c|}
\hline $\mathbf{S}$ & $x_{1}$ & $x_{2}$ & $x_{1}^{2}$ & $x_{2}^{2}$ & $x_{1} \cdot x_{2}$ & $y_{1}$ \\
\hline$x_{1}$ & 1 & & & & & \\
\hline$x_{2}$ & 0 & 1 & & & & \\
\hline$x_{1}^{2}$ & 0.99 & 0 & 1 & & & \\
\hline$x_{2}{ }^{2}$ & 0 & 0.98 & 0 & 1 & & \\
\hline$x_{1} \cdot x_{2}$ & 0.54 & 0.75 & 0.780 & 0.76 & 1 & \\
\hline$y_{1}$ & 0.42 & 0.49 & 0.43 & 0.52 & 0.72 & 1 \\
\hline
\end{tabular}

Approximation of the experimental data for energy germination was performed by quadratic and gives the regression equation:

$$
y_{1}=86.4-0.62 x_{1}+0.23 x_{2}+0.03 x_{1} \cdot x_{2}+0.03 x_{1}^{2}+0.03 x_{2}^{2} .
$$


The quality of the mentioned model was estimated by the multiple coefficient of correlation $R$, which turned out to be sufficiently high and equal to $R=0.86$. This suggests that the degree of polynomial approximant should not be worth increasing. The high coefficient of multiple determination $\left(R^{2}=0.74\right)$ also indicates the quality of the model. The significance of polynomial approximant coefficients was verified using the Student's test (with $5 \%$ significance level). All of them proved to be significant. The obtained critical value of the Student's parameter turned out to be equal $t_{c r}=2.093$ and superior to the observed values of coefficients. Hence, none of them can be neglected in the polynomial approximant. The quality control of the concerned model was conducted by the Fisher's test. The computed size of the Fisher's test is equal to $F_{o b c}=R^{2} \cdot 460 /\left(1-R^{2}\right)=122$ and the critical value is equal to $F_{c r}=3.21$. As $F_{o b c}>F_{c r}$, the hypothesis about the statistical significance of the obtained regression is worth recognizing to be true.

For the obviousness, Figure 1 graphically illustrates the diagram of the effect of the processing time and pulse duration on the value of energy germination, the value of which is computed according to the equation (1).

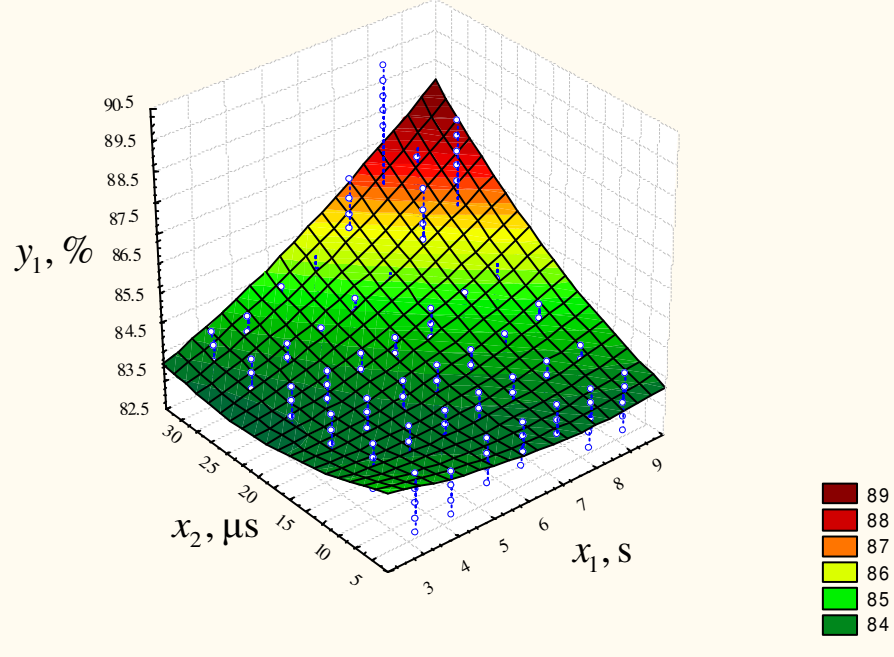

Fig. 1. Diagram of effect of processing time $-x_{1}$ and pulse duration $-x_{2}$ on value of germination energy $-y_{1}$

As evident from the diagram, the rational quantities of the processing time and pulse duration are the following: $t_{\text {pro }}=8 \mathrm{~s} ; \tau_{\text {imp }}=35 \mu \mathrm{s}$,

The second model determines the dependence of the germination energy $-y_{1}$ on the processing time duration $-x_{1}$ and the amplitude of the voltage pulse $-x_{3}$. The third model demonstrates the dependence of the germination energy $-y_{1}$ on the processing time $-x_{1}$ and voltage pulse frequency $x_{4}$. The statistical treatment of the experimental data obtained for these models were performed similarly as for the first model, and corresponding regression equations are obtained

$$
\begin{gathered}
y_{1}=86.13-0,44 x_{1}+1.23 x_{3}+0.04 x_{1} \cdot x_{3}-0.1 x_{1}^{2}-0.08 x_{3}^{2} . \\
y_{1}=62.63+3,58 x_{1}+3.36 x_{4}-0.17 x_{1} \cdot x_{4}-0.18 x_{1}^{2}-0.15 x_{4}^{2} .
\end{gathered}
$$

The approximation of correlations (2) and (3) of quadratic is obtained on the basis of the corresponding correlation matrixes, where correlation coefficients are nearly equal to unity, and consequently, they are important and should be taken into account. The multiple coefficient of correlation and the coefficient of multiple determination for these models were also quite high and equal to 0.81 and 0.86 , correspondingly, 0.66 and 0.74 , correspondingly. According to the Fisher's test, the quality of the second model was appraised. The size of the Fisher's test $F_{o b c}=136$ and its critical value $F_{c r}=3.35$ were computed. As $F_{o b c}>F_{c r}$, the hypothesis about the statistical significance of regression (2) is worth recognizing to be true. By analogy, the statistical significance of regression (3) is confirmed by the calculation of the corresponding Fisher's test and its critical value: $F_{o b c}=120$, 
$F_{c r}=3.21$. The diagram of the effect of the processing time duration and voltage amplitude on the value of germination energy is presented in Figure 2.
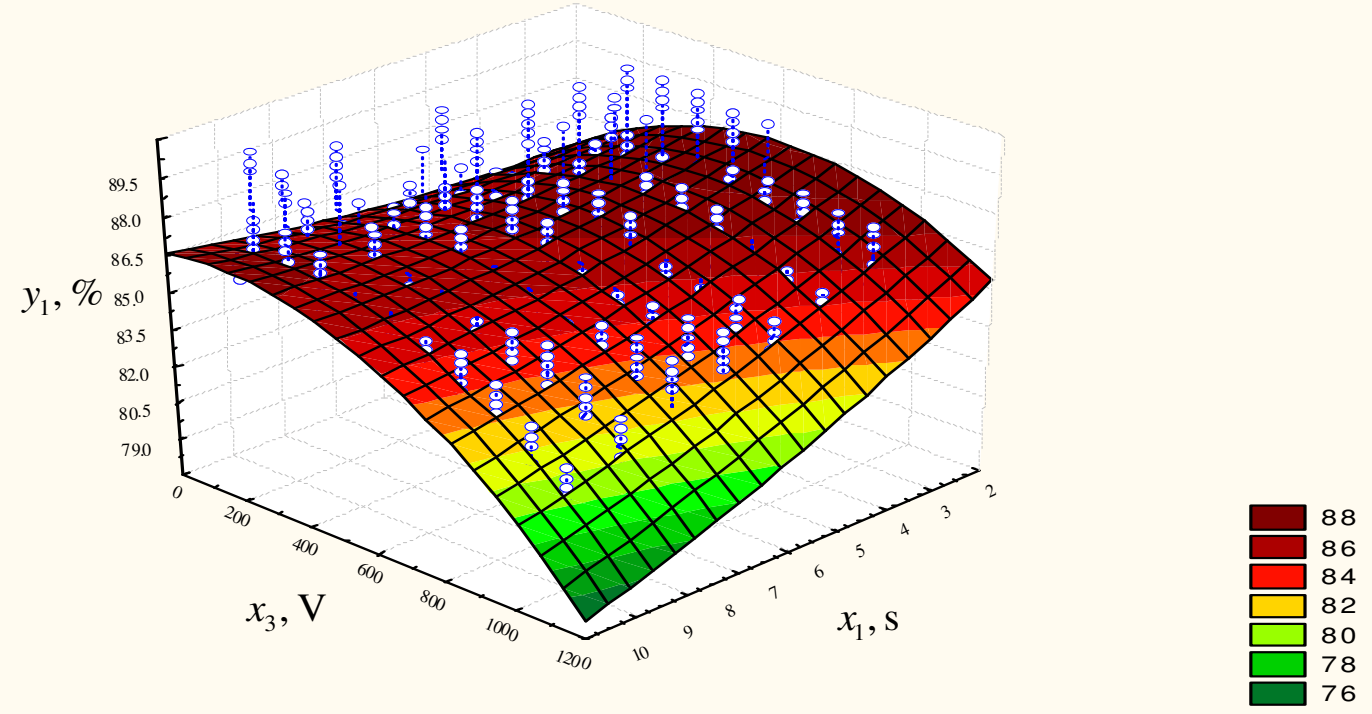

Fig. 2. Diagram of effect of processing time duration $-x_{1}$ and voltage amplitude $-x_{3}$ on values of germination energy $-y_{1}$

According to Figure 2, the rational values of the treatment parameters, which increase the germination energy as much as possible, are the following in the observed model: $t_{p r o}=8 \mathrm{~s}, u=200 \mathrm{~V}$.

The diagram of the effect of the processing time and the pulses frequency on the values of germination energy is presented in Figure 3.
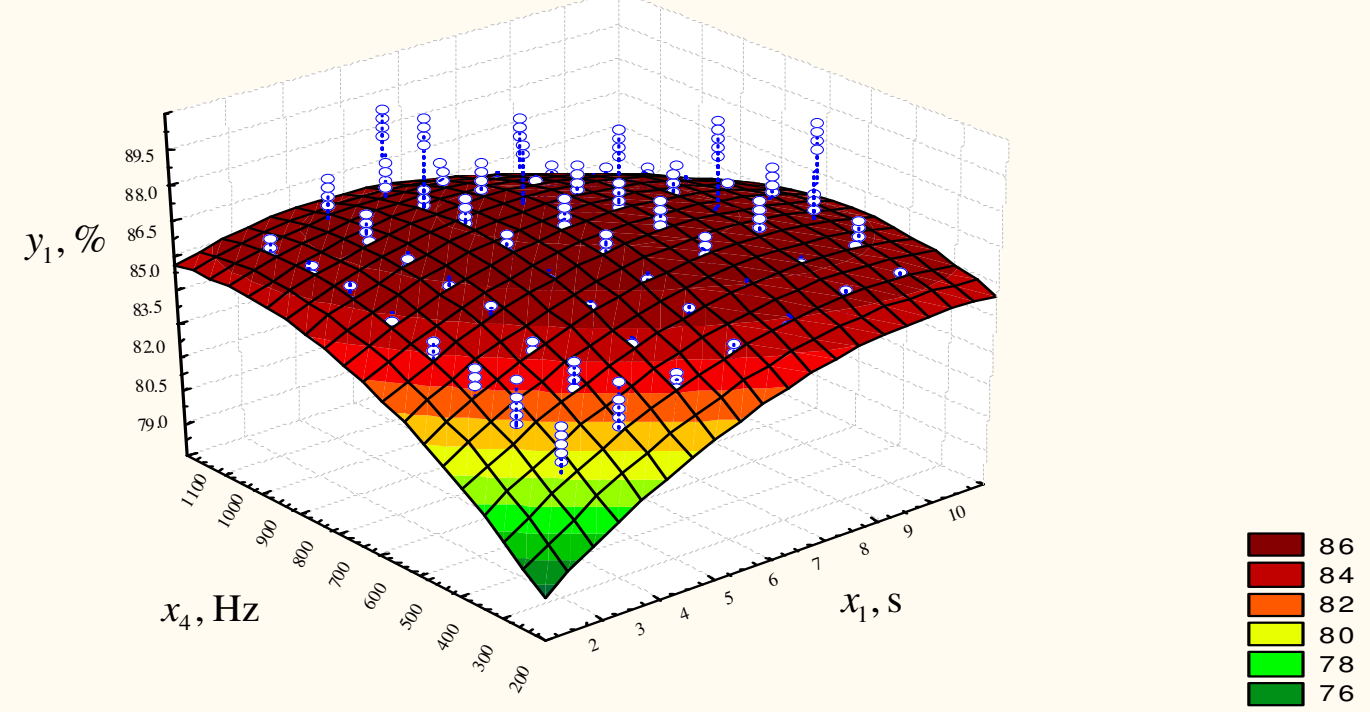

Fig. 3. Diagram of effect of processing time $-x_{1}$ and frequency of voltage pulses $-x_{4}$ on values of germination energy $-y_{1}$

According to the diagram of Figure 3, the rational values of the treatment parameters for the third model are equal correspondingly: $t_{p r o}=8 \mathrm{~s}$ and $\mathrm{f}=600 \mathrm{~Hz}$.

Generalizing the results of three models of regression analysis, it can be concluded that in order to stimulate the effect on onion seeds for improving their sowing quality it is necessary to accomplish their presowing treatment by the PEF in the mode with the following parameters:

$$
t_{\text {pro }}=8 \mathrm{~s}, \tau_{\text {imp }}=35 \mu \mathrm{s}, \mathrm{f}=600 \mathrm{~Hz}, \mathrm{u}=200 \mathrm{~V} .
$$


At the same time, the seed germination energy was increased by $7.9 \%$ on the average compared with the control untreated seeds.

It should be noted that a convenient integral test connecting all principal parameters of seed treatment $(\mathrm{PEF})$ is an amplitude doze of effect being computed according to the ratio [19]:

$$
D=E \cdot \tau_{\text {imp }} \cdot f \cdot t_{\text {pro }} .
$$

In accordance with (4), for the established rational treatment mode, we get the value $672 \mathrm{~V} \cdot \mathrm{s} \cdot \mathrm{m}^{-1}$ (for $E=4 \mathrm{kV} \cdot \mathrm{m}^{-1}$ ). For comparison, the following parameters were obtained in the rational mode of seed treatment (PFE) in a high-voltage installation:

$$
t_{\text {pro }}=840 \mathrm{~s}, \tau_{\text {imp }}=5 \mathrm{~ns}, f=300 \mathrm{~Hz}, u=15000 \mathrm{~V} .
$$

To which the amplitude doze of the effect numerically equal to $630 \mathrm{~V} \cdot \mathrm{s} \cdot \mathrm{m}^{-1}$ (for $E=1.5 \mathrm{kV} \cdot \mathrm{m}^{-1}$ ) is corresponded. It means that presowing treatment of onion seeds by the PFE in the low- voltage installation is equivalent to the effect of their presowing treatment in the high voltage installation.

It should be noted that the statistic treatment of the obtained experimental data for germination of treated onion seeds by the PFE has also been performed. The increase of seed germination has been $9 \%$ on the average, if compared with control untreated seeds.

On the experimental university farm, the single check was conducted concerning the established rational mode of presowing treatment of onion seeds "Holtsedon" variety by seed sowing on two identical land plots with an area of $100 \mathrm{~m}^{2}$. The harvest was $427 \mathrm{~kg}$ of onion on the tested plot, and $400 \mathrm{~kg}$ of onion on the control plot. Consequently, the yield increase was $27 \mathrm{~kg}(6.8 \%)$ that points out a positive result of the observed presowing seed treatment.

\section{Conclusions}

The rational parameters of the presowing treatment mode of onion seeds have been obtained experimentally, allowing to increase the seed germination energy by $7.9 \%$ (up to $77.9 \%$ ), on the average and germination by $8.5 \%$ (up to $91 \%$ ) in comparison with the control untreated seeds. The given rational mode can be practically used to improve sowing quality of onion seeds prior their sowing.

\section{Reference}

[1] Reddy P., Mycock D. J., Berjak P. The effect of microwave irradiation on the ultrastructure and internal fungi of soybean seed tissues / Seed Science and Technology, 2000, vol. 28, № 2, pp. 277-289.

[2] Knox O.G.G, McHugh M.J., Fountaine J.M., Havis N.D. Effects of microwaves on fungal pathogens of wheat seed/ Crop Protection. August 2013, vol. 50, pp. 12-16.

[3] Friesen A. P., Conner R.L., Robinson D.E., Barton W.R., Gillard C.L. Effect of microwave radiation on dry bean seed infected with Xanthomonasaxonopodispvphaseoli with and without the use of chemical seed treatment / Crop Protection, 2014, vol. 65, November 01, pp. 77-85.

[4] Gholami A., Sharafi S., Abbasdokht H. Effect of Magnetic Field on Germination of Two Wheat Cultivars / International Scholarly and Scientific Research and Innovation, 2010, vol.4. №8, pp. 1366-1368.

[5] Carbonell M. V., Martinez E., Amaya J. M. Stimulation of Germination of Rice by Static Magnetic Field / Electro and Magnetobiology, 2000, vol. 19, №1, pp. 121-128.

[6] Moon J. D., Chung H. S. Acceleration of germination of tomato seed by applying AC electric and magnetic fields / Journal of Electrostatics, 2000, vol. 48, №2, pp. 103-114.

[7] Xu Y., Guo S., Jia G., Zhang N., Song Z., Xu G., Zhang C., Li F. Effect of corona discharge field processing on vigor of three layers of paddy seeds / Transactions of the Chinese of Agricultural Engineering, 2015, vol. 31, pp. 307-314.

[8] Kubisz L., Holubowicz R., Gauza M., Hojan-Jezierska D., Jaroszyk F. Effect of low frequency magnetic field on germination of onion (Allium cepa L.) seeds / ActaPhysicaPolonica A,2012, vol. 121, № 1A, pp. A49-A53. 
[9] De Souza A., Garcia D., Sueiro L., Gilart F., Improvement of the seeds germination, growth and yield of onion plants by extremely low frequency non-uniform magnetic field / Scientia Horticulturae, 2014, vol. 176, №11, pp. 63-69.

[10]Хайновский В.И., Стародубцева Г.П., Рубцова Е.И. Применение импульсного электрического поля для предпосевной стимуляции семян сои (Application of a pulsed electric field for presowing stimulation of soybean seeds) / Механизация и электрификация сельского хозяйства. - 2008. - № 7. - C.9-11. (In Russian)

[11]Данилов Д.В., Стародубцева Г.П., Хайновский В.И. Предпосевная обработка семян сахарной свеклы импульсным электрическим полем (Presowing treatment of sugar beet seeds by a pulsed electric field) / Механизация и электрификация сельского хозяйства.- 2008.- № 6. - C.7-9. (In Russian)

[12]Дульский А.Н., Стародубцева Г.П., Хайновский В.И. Предпосевная обработка семян моркови сорта «Витаминная-6» импульсным электрическим полем (Presowing treatment of carrot seeds of "Vitamin-6" variety with a pulsed electric field) / Вестник РАCXН. 2009. №6. C.59-60. (In Russian)

[13] Хайновский В.И., Любая С.И., Копылова О.С., Афанасьев М.А. Предпосевная обработка семян (Presowing seed treatment) / Сельский механизатор. 2017. № 1. С. 14-15. (In Russian)

[14] Vitázek I., Vereš P. Drying Rate of Grain Maize / Acta Technologica Agriculturae, 2013.Vol.16, № 2, p. 31 .

[15] Novák J. Electrical PropeRties of Popcorn Grains / Acta Technologica Agriculturae, 2013.Vol.16, № 2, p.43.

[16] Novák J., Vitázek I. Electrical Properties of Sunflower Achenes / Acta Technologica Agriculturae, 2014.Vol.17, № 4, p.109.

[17] Хныкина А.Г., Рубцова Е.И., Копылова О.С., Хайновский В.И. Электрические и механические параметры активатора импульсного электрического поля (Electrical and mechanical parameters of the pulsed electric field activator) / Вестник АПК Ставрополья. 2015. № 3 (19). С. 55-59. (In Russian)

[18] Хайновский В.И., Стародубцева Г.П., Рубцова Е.И., Копылова О.С., Никитин П.В., Любая С.И. Моделирование электрических временных параметров активатора импульсного электрического поля (Modeling of electrical time parameters of a pulsed electric field activator) / Вестник АПК Ставрополья. 2016. № 2 (22). с. 39-44. (In Russian)

[19] Хайновский В.И., Копылова О.С., Козырев А.Е. «Расчет доз воздействия импульсного электрического поля на семенной материал» (Calculation of the doses of the action of a pulsed electric field on the seed material) / Аграрная Россия, 2012, №9, с.37-42. (In Russian) 